\title{
Ecological Architectural Design Education Practices Via Case Studies
}

\author{
Ekolojik Mimari Tasarım Eğitimi Uygulamalarının \\ Örnekler Üzerinden Değerlendirilmesi
}

\author{
Derya GÜLEÇ ÖZER, ${ }^{1}$ Bülent Onur TURAN ${ }^{2}$
}

\section{ABSTRACT}

This paper presents two case studies conducted in Architectural Design education in order to meet understanding and ability criteria in MIAK (Turkish Architectural Accrediting Board) and NAAB (National Architectural Accrediting Board) for 'sustainability'. The main purpose of this clause is to reinforce students' ability to design projects that optimize, conserve or reuse natural and built resources; their ability to provide healthy environments for occupants/users, and reduce the environmental impacts of building construction and operations on future generations through such means as carbon-neutral design, bioclimatic design, and energy efficiency. First-year undergraduate architecture students provided the setting for Case Study 1. A comparative study was implemented in a basic design studio between two distinct groups (a test group and a control group) mandated specifically with awareness raising. At semester's end, both groups' projects were reviewed and evaluated via questionnaire. Third-year undergraduate architecture students provided the setting for Case Study 2. An experimental study was carried out within the context of green design education, with the purpose of reinforcing understanding and ability of sustainability issues. The overall aim was to integrate building energy performance assessment into the design studio as a design decision support tool. As in Case Study 1, there were two groups. Students in the control group followed the conventional design process, while those in the test group tested the environmental performance of their proposals with computational models and energy simulations carried out with Ecotect v5.20. The conclusion reached was that a conventional design process is inadequate for a multidisciplinary knowledge-based studio aiming to integrate the theoretical basis of the energy-ecology field with architectural studio practice.

\section{ÖZET}

Bu makale, mimari tasarım eğitimi alanında MIAK (Türk Mimarlık Akreditasyon Kurulu) ve NAAB'ta (Mimarlık Akreditasyon Kurulu) yer alan 'sürdürülebilirlik' kriterini, anlama ve yapabilme üzerinden iki farklı uygulama ile değerlendirmeyi öngörmektedir. Bu kriterin temel amacı, öğrenci projelerinde yapı ve doğal kaynakları optimize etmeleri, koruma ve yeniden kullanımı; kullanıcılar için sağlıklı çevreler oluşturabilmeleri; bina inşaa aşamasında karbon emisyonunu azaltacak önlemler almaları; biyoklimatik tasarıma ve enerji verimliliğine önem vermeleridir. Mimarlık 1. sınıf öğrencileri Uygulama No: 1 çalışmasını oluşturmaktadırlar. Temel tasarım stüdyosunda, test ve kontrol grupları adı verilen iki farklı grup üzerinde, bilinci arttırmayı hedef alan karşılaştırmalı bir çalışma ortaya konulmuştur. Dönem sonunda her iki grup da bir anket üzerinden değerlendirilmiştir. Mimarlık 3. sınıf öğrencileri ise Uygulama No: 2 çalışmasının alt yapısını oluşturmuştur. Ekolojik tasarım kriterleri ışığında, sürdürülebilir kriterleri anlama ve yapabilme kavramı üzerine deneysel bir çalışma yapılmıştır. Amaç, bina enerji performans uygulamalarını, tasarım stüdyosuna, bir tasarım kararı destek aracı olarak entegre etmektir. Uygulama No: 1 de olduğu gibi yine iki grup üzerinde çaIışılmış; kontrol grubu öğrencileri konvansiyonel süreci takip ederken, test grubu, Ecotect $v 5.0$ programı ile birlikte projelerini bilgisayar destekli enerji simulasyon aracı ile geliştirmişlerdir. Sonuçta, enerji-ekoloji tabanlı bilgi birikimini tasarım stüdyosu eğitimine entegre etmek isteyen multidisipliner bir stüdyo eğitiminde, konvansiyonel metodların yeterli olmadığı ortaya konulmuştur.

'Department of Architecture, School of Engineering and Architecture, Istanbul Kemerburgaz University, Istanbul; ${ }^{2}$ Department of Informatics, Mimar Sinan Fine Arts University, Istanbul.

'Istanbul Kemerburgaz Üniversitesi Mühendislik ve Mimarlık Fakültesi, Mimarlık Bölümü, İstanbul;

${ }^{2}$ Mimar Sinan Güzel Sanatlar Üniversitesi, Enformatik Bölümü, Istanbul.

Article arrival date: November 21, 2014 (Başvuru tarihi: 21 Kasım 2014) - Accepted for publication: March 11, 2015 (Kabul tarihi: 11 Mart 2015)

Correspondence (Illetişim): Derya GÜLEÇ ÖZER. e-mail (e-posta): deryagulecozer@gmail.com

๑ 2015 Yıldız Teknik Üniversitesi Mimarlık Fakültesi - @ 2015 Yıldız Technical University, Faculty of Architecture 


\section{Introduction}

In order to develop the concept of "sustainable architecture," which is increasingly prominent with environmental concerns, it is crucial to incorporate notions of energy and ecological consciousness into design education. Today's architecture students are the next generation of architects. In architectural design education, decisions that are taken during the early phases of the design process play a very important role in ensuring the performance of the final product. The main problem of knowledge-based design processes is the incapability of interpreting or evaluating the outcome of intuition-based decisions, so as to provide reliable environmental sustainability criteria.

The MIAK ${ }^{1}$ (Turkish Architectural Accrediting Board) and related $\mathrm{NAAB}^{2}$ (National Architectural Accrediting Board), had announced a set of student performance criteria (SPC). These criteria encompass two levels of accomplishment:

(1) Understanding - The capacity to classify, compare, summarize, explain and/or interpret information.

(2) Ability - Proficiency in using specific information to accomplish a task, correctly selecting the appropriate information, and accurately applying it to the solution of a specific problem, while also distinguishing the effects of its implementation.

The SPC are organized into 3 realms in order to facilitate the expression of the relationships. Realm A: Critical Thinking and Representation; realm B: Integrated Building Practices, Technical Skills and Knowledge; realm C: Leadership and Practice. In Realm B, 'sustainability' is a B3 clause. The aim is that students gain "the ability to design projects that optimize, conserve, or reuse natural and built resources, provide healthful environments for occupants/users, and reduce the environmental impacts of building construction and operations on future generations through means such as carbon-neutral design, bioclimatic design, and energy efficiency." ${ }^{3}$

In order to meet the MIAK and NAAB criteria in sustainability issues, this study aimed to integrate ecological design with architectural design education, step by step, by case studies. In the first year of education, the integration of ecological concepts into basic design studio (Case Study No 1) aims to raise awareness. In the third year of education, the integration of specific theoretical courses into design studios (Case Study No

\footnotetext{
1 MIAK Web Site: www.miak.org $\quad 2$ NAAB 2009 Criteria. 3 Ibid.
}

2) aims to understanding and ability concerning sustainability issues.

First-year undergraduate architecture students provided the setting for Case study No1. ${ }^{4}$ A comparative study was implemented in the Basic Design studio between two distinct groups specified under the scope of raising awareness: a test and a control group. Both groups were given the same problem throughout the semester: to design a house with full technical drawing details, models and presentations. As the aim of the study was to introduce sustainability issues into basic design education and also raise awareness, the test group was introduced to sustainability concepts. Towards the end of the semester, this group was offered a seminar on sustainability and energy efficient ecological design. Students were asked to work on their projects, while concentrating on the issues raised by the seminar for a few more weeks. At the end of the semester, both groups' projects were reviewed and evaluated though a questionnaire.

Third-year undergraduate architecture students provided the setting for Case Study No2., ${ }^{5,6}$ An experimental study was carried out within the context of green design education, with the purpose to reinforce understanding and ability of the sustainability issues. The overall aim was to integrate building energy performance assessment into design studio as a design decision support tool. As in Case Study No.1, there were two groups: a test and control group. Students in the control group followed the conventional design process whereas students in the test group tested their proposals' environmental performance with computational models and energy simulations carried with Ecotect v5.20. Both groups were given the same program, scale and site for the design problem in order to conduct comparative evaluations of the design process and outputs. The conclusion that was extracted from the result was that conventional design process is not satisfactory for a multidisciplinary knowledge based studio that aims to integrate the theoretical basis of energy-ecology field with the architectural studio practice.

Based on the observations and evaluations, it may be argued that the major parameters to be considered in such an integrated studio approach to architectural education are:

- Sufficient background knowledge on digital technologies

\footnotetext{
4 Ozer et. al, 2012, p.349.

${ }^{6}$ Ozer, Utkutug, 2010b, p. 260.

Ozer, Utkutug, 2010a, p. 47
} 
- Self-discipline for studio work

- Architectural design potential and enthusiasm

- Teaching experience in related fields and computer aided environmental design

- Well equipped studio infrastructure for computer aided environmental design

- Flexible time opportunities necessary for design processes of varying levels of student profiles.

\section{Integration of Theory and Practice in Architectural Design Education}

Architectural design education forms a unity with architectural design studio courses and theoretical courses supporting them. Core design studio is the fundamental course for initating the process in the first year of education. The main purpose of this fundamental design studio course is to teach "the language of design" by introducing students to 2D and 3D tools of thinking in order to produce high quality spaces. ${ }^{7}$ In the first semester, the primary objective is to introduce abstract thinking and formal analysis techniques. The second objective is the basic architectural problem: to introduce spatial concepts. In the second semester, the focus is displaced on space generation, with the introduction of three dimensional design and generation techniques.

Formal architectural education is comprised of theoretical and practical courses which neccessitate the candidate's participation. Architectural design education is the most dominant part of this structure, offered through design studios. The architectural design studio, which is defined by Koester as a "studying space for a talented person," involves a doing-undoing, an experiencing space for channeling creativity into architecural design education. Koester ${ }^{8}$ defines the active learning space of a studio as an inspring and creative experience that is also adored by students.

In his book "Design Studio", Schon ${ }^{9}$ has pointed out that novice designers are not fully experienced in problem solving skills. He explains that the reasons are the discrepancies between thought and actions. Schon ${ }^{10}$ notifies the "reflection in action" theory, pointing out that basic design knowledge can only be obtained by "doing." Therefore all theoretical information should be integrated into design studio by doing, undoing, and experiencing.

\footnotetext{
Arkun et. al., 2000, p.39.
}

8 Koester, 2006, p. 659.
9 Schon, 1985, p. 105.

${ }^{10}$ Schon, 1987 , p. 70.

\section{Energy Conscious Ecological Building Design} Exercises in the Literature

In the context of the increasing problems of the built environment, there are environmental issues to be addressed. These issues have to be taken into account in architectural education in order to educate future generations. Also, the process of addressing sustainable environmental design concepts must be efficiently integrated into design education. ${ }^{11}$ In his book "Designing with Nature", Yeang mentions that 'ecology' and 'environmental biology' should be reconsidered in the areas of architectural education. The traditional approach should be revised according to eco-design perspective. ${ }^{12}$ The conventional design approach that is still adopted today, does not take such problems of environmental design into account. Therefore, "unconscious" architects are raised, because a non-appropriate manner is adopted; a manner which does not keep up with the development of the technology. At the end of his studies on architectural education, Koester argues that the concept of sustainability should be contextualized as the method to create the best design studio education. ${ }^{13}$ In general framework, energy and ecological issues are placed in the cirricula and philosophy of architecture schools as one of the lowest branches of Architecture worldwide. Environmental sciences are created as an independent faculty.

In 1993, the University of Melbourne School of Architecture-Building and Planning introduced environmental programs, in order to connect multi-disciplinary scientific data with the design process. As a consequence, fundamental philosophical and social phenomena were revived, besides questions of knowhow, know-why and know-what of basic technical knowledge. ${ }^{14}$ At the end of the theoretical training, Radovic questioned how to integrate these Environmental Design issues into 'traditional' architectural studios, in order to shed light on future studies.

Similarly, since 1997, the Department of Architecture of Eastern Mediterranean University introduced courses on the field of energy and ecology in the studies, in order to construct a method to integrate into the design studios. ${ }^{15}$ Undergraduate and graduate level courses, field trips and seminars are supported by the group work. However, integrated studio environment is not constructed yet.

The introduction of environmental design, sustain-

\footnotetext{
${ }^{11}$ Tabb, Rashed-Ali, 2006, p.623. $\quad{ }^{14}$ Radovic, 1998, p. 627.

12 Yeang, 1995, p.187.

${ }^{13}$ Koester, 2006, p. 660.
} 
ability, and information technology-based courses (IT / web) in various universities, ${ }^{16}$ has provided input in the design process of these studio courses. The main purpose of the described integration of studio education is to improve the education system by integrating ecological data into architectural design education. The purpose of transferring knowledge about issues of sustainability to novice architects is to use this awareness to inspire the design process. The purpose of these supplemental studio courses is to teach basic laws of physics and basic behaviours of buildings; ${ }^{17}$ and to structure the infrastructure of the education via environmental design, passive design and resource efficiency topics.

Roulet conducted a workshop with the aim to raise awareness on ecological architecture among architecture students at the École Polytechnique Fédérale de Lausanne for a period of 4 years. ${ }^{18}$ Roulet pointed out that there is always a conflict between aestheticcost and low-energy-use and good indoor comfort in architectural practice. However, recent examples have shown that this judgement is not true at all. In this manner, the students appear to use these theoretical courses and all the knowledge on sustainable architecture in the design process.

The integration of conceptual and analytical approaches of sustainable Architecture in the "Sustainable Environmental Design Studio" Master program in AA in London, aimed to enrich the design research and practice with a creative phenomenon. ${ }^{19}$ In this context, Yannas, one of the most significant researchers in this field, made important observations on studio education integration. Master studio coordinator Yannas, argued that there is not a formula to integrate theoretical knowledge to design work, based on the observation that some students manage to integrate both processes, while some students adopt concepts to add afterwards. He contended that different teaching methods do not affect the speed, ease or productivity of the design process. He argued that as long as time is a critical factor, the design projects improved day by day, and reaped the rewards of the labor.

The main result to be extracted from this study and be taken into account is the efficient use of time factor. 'Modelling' phase in simulations, may become very challenging and time-consuming for novice architects, because there is usually not enough time for performace analysis results.

${ }^{16}$ Hensen et. al., 1998, p.623.

17 Fuchs, Simon, 1995, p.362.

${ }^{18}$ Roulet, 2006, p.25.

19 Yannas, 2006, p. 25
The study that Hamza and Horne conducted in Northumbria University, aims to develop strategies to achieve energy conservation in the design process. Project basically integrates 3 course modules (1. Design studio, 2.Structure envelope and environment, 3. Computer aided visualization and 3D modelling). ${ }^{20}$ The courses are structured to support each other for a period of one year.

Based on these studies, the vision is to create the best studio practices through integration of theoretical courses and simulation exercises. As mentioned, the aim of the first year of education is to raise awareness whereas the aim of the third year education is to raise understanding and ability.

\section{Case Study No 1: Basic Sustainability Issues in First Year}

\section{Ecological Design Fundamentals in Basic Design Education}

Architectural practice has generated new discourses in different areas, especially in the past 20 years. Largely shaped by the discourses of technology, new innovative developments put forward the area of architectural education as well as the area of architectural practice. Throughout the architectural education, basic design studio is the starting point for introducing the architectural concepts and space generation. One of the most important concepts to be introduced is "sustainability" in education and practice of architecture.

In order to educate future generations of architects in the context of ever increasing environmental problems concerning the built environment, the aforementioned issues should be brought up in architectural education agenda; sustainable environmental design concepts should be efficiently integrated into design educational process. ${ }^{21}$ Yeang ${ }^{22}$ states that architectural education's "traditional" standpoint should be revised according to ecological design approach. Unfortunately, "conventional design education ignoring environmental design issues" is still adopted today and unconscious architects are raised; moreover, the educators have not exhibited an appropriate manner to keep up with technology. Koester ${ }^{23}$ argues that sustainability issues should be adopted as the method to build up the best design studio education.

Many studies have been conducted concerning architectural education literature from undergradute to graduate level. These studies include ecological stu-

\footnotetext{
${ }^{20}$ Hamza, Horne, 2007, p. $3841 . \quad 22$ Hui, 1998, p.40.

${ }^{21}$ Tabb, Rashed-Ali, 2006, p. $623 . \quad{ }^{23}$ Koester, 2006, p. 659.
} 


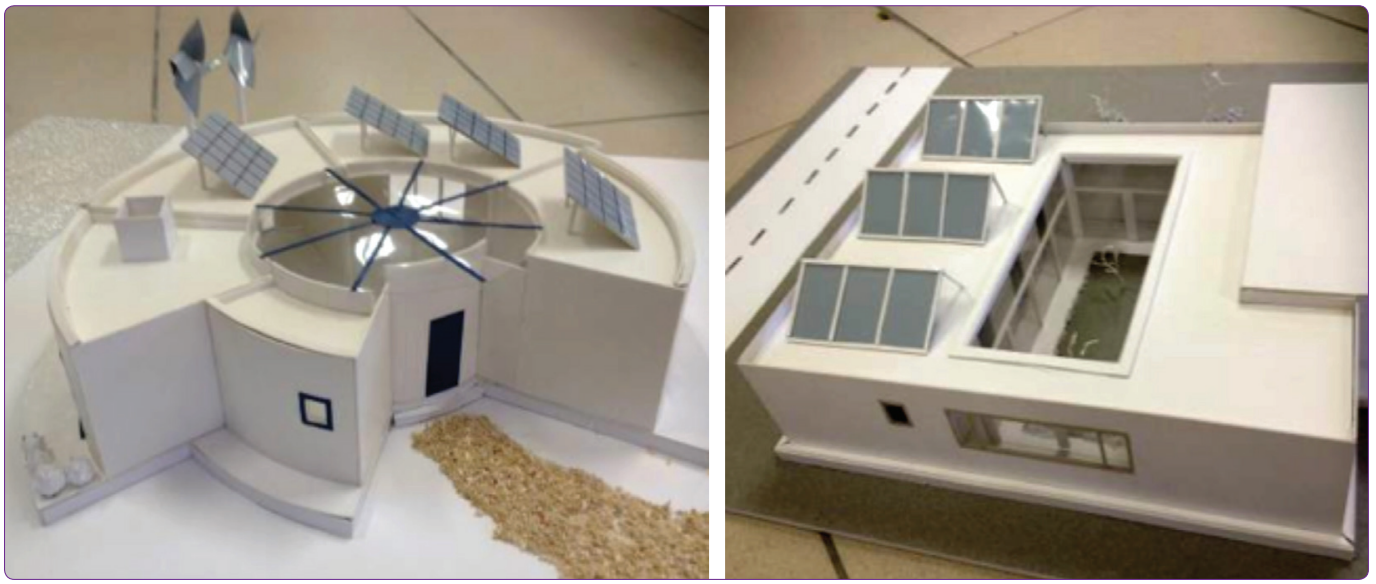

Figure 1. Models of the final house projects, test group students (Left: Seyma Hancer, Right: Sena Hardal).

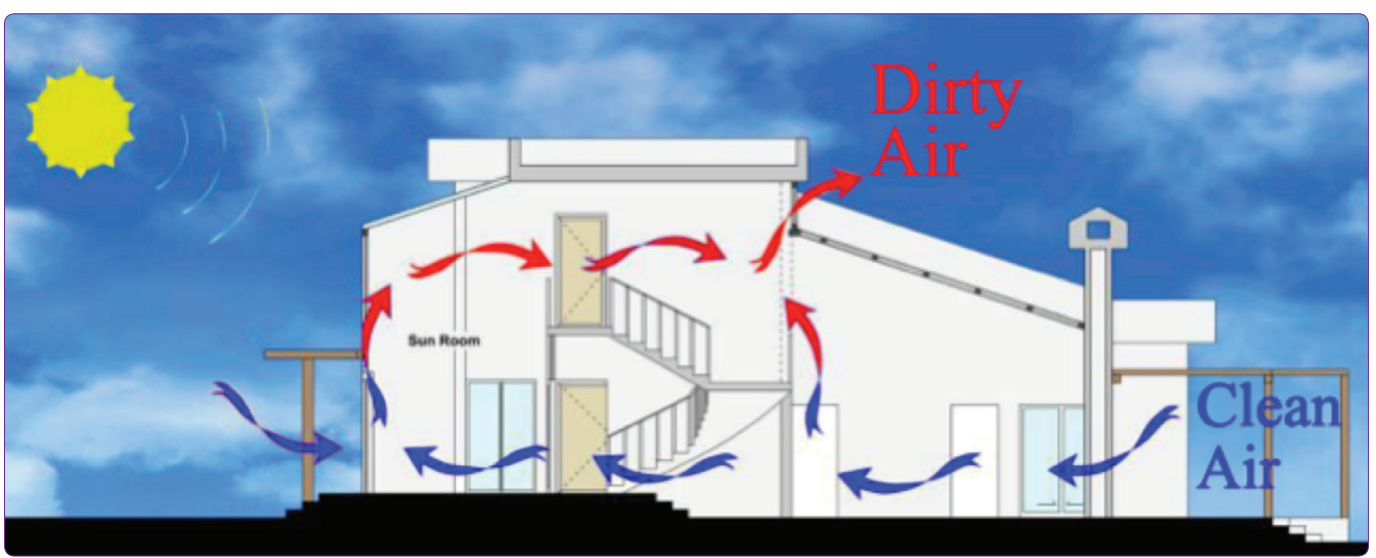

Figure 2. Section diagram of natural ventilation of a test group student (Berkay Firat).

dio integration, ${ }^{24-27}$ sustainable environmental design studio, ${ }^{28}$ ecological awareness workshops ${ }^{29}$ and environmental design education studies. ${ }^{30,31}$ The common theme in these works has been the integration of sustainability issues to architectural education and raising awareness among students.

In accordance to these studies, a study has been conducted within the basic design studio process, introducing sustainable design issues and being aware of environmental problems and ecological concepts. In order to achieve this integration, the facts that should be introduced into design studio environment are:

- Energy/ecology/sustainability concepts and their use in architecture

- Raising awareness about environmental problems and introducing sustainable architecture.

\footnotetext{
${ }^{24}$ Ozer, Utkutug, 2010, p.47.

${ }^{25}$ Hensen et. al., 1998, p. 623.

${ }^{26}$ Fuchs, Simon, 1995, p.362.

${ }^{28}$ Yannas, 2006, p.25.

${ }^{29}$ Roulet, 2006, p. 653.

${ }^{30}$ Radovic, 1998, p. 627.

${ }^{27}$ Hamza, Horne, 2007, p. 3841.

${ }^{31}$ Ozer, Harmankaya, 2010, p. 862.
}

\section{Method of the Study}

In order to implement a comparative study in basic design studio, two distinct groups were specified. Both were given the same problem of a house design with full technical drawing details, models and presentations throughout the semester. The aim of the study was to introduce sustainability issues into basic design education and to raise awareness. Therefore, a test group was specified to introduce the new concepts. Near the end of the semester a seminar was given to this group on sustainability and energy efficient ecological design. Students were asked to work on their projects concentrating on these issues a few weeks more. A control group was specified in order to compare the results. At the end of the semester, the projects of both groups were reviewed and a questionnaire was conducted.

\section{Section Results}

Besides the common agenda, a sustainable design seminar is given to the specified test group on week $13^{\text {th }}$. On weeks $14^{\text {th }}$ and $15^{\text {th }}$, the designs are subjected 
Table 1. Evaluation of basic design concepts (TG, 23 students are evaluated)

Question: In house design, I have gained knowledge about "the following concepts"

\begin{tabular}{lccccc}
\hline & Totally agree (\%) & Agree (\%) & Neutral (\%) & Disagree & Totally disagree \\
\hline Functional scheme & 16 students (70) & $7(30)$ & - & - & - \\
Space Layout & $12(52)$ & $11(48)$ & - & - & - \\
Zoning & $13(56)$ & $8(35)$ & $2(9)$ & $1(4)$ & - \\
Technical drawing & $11(48)$ & $11(48)$ & $3(13)$ & - & - \\
Green architecture & $5(22)$ & $15(65)$ & $3(13)$ & - & - \\
Overall evaluation & $6(26)$ & $14(61)$ & & - \\
\hline
\end{tabular}

Table 2. Evaluation of basic design concepts (CG, 17 students are evaluated)

Question: In house design, I have gained knowledge about "the following concepts"

\begin{tabular}{lccccc}
\hline & Totally agree (\%) & Agree (\%) & Neutral (\%) & Disagree (\%) & Totally disagree \\
\hline Functional scheme & 8 students (47) & $9(53)$ & - & - & - \\
Space Layout & $8(47)$ & $9(53)$ & - & - & - \\
Zoning & $5(29)$ & $8(47)$ & $4(24)$ & - & - \\
Technical drawing & $7(41)$ & $10(59)$ & $6(35)$ & $1(6)$ & - \\
Green architecture & $3(18)$ & $7(41)$ & $4(23)$ & - & - \\
Overall evaluation & $4(23)$ & $9(53)$ & & - \\
\hline
\end{tabular}

to evaluation from a sustainable architectural viewpoint. At the end of the semester, the students in the control group made comparisons with the test group.

Evaluating test group students' design process and final works, students seemed to focus on orientation, energy efficiency, use of shading elements to prevent sun and photovoltaic panels to produce electricity (Figure 1). Inner courtyards were used in order to provide natural lighting to the interior spaces (Figure 1). Most students focused on comfort zones in their projects. Natural ventilation was raised to an important design criterion in some of the projects (Figure 2).

After the first three weeks of work focusing on sustainable issues, a questionnaire was given out to the students; 23 of the test group and 17 of the control group, and questionnaires were collected back. The questionnaire aimed to measure their awareness on the sustainable and ecological design issues, their process throughout the semester and to collect overall opinions.

In the first section of the questionnaire, questions were asked to evaluate the students' knowledge on basic design concepts, such as functional scheme, space layout, zoning, technical drawing skills, and green architecture. In the end, students were asked for an overall evaluation on their knowledge.

Concerning the concept of functional scheme, the comparison showed that test group students are better than "totally agreed students," more specifically $70 \%$ (test group-TG) to $47 \%$ (control group-CG). Concerning the concept of space layout, TG students are better than "totally agreed students," in a percentage of $52 \%$ (TG) to $47 \%$ (CG). Concerning the concept of zoning, TG students are better than "totally agreed students," in a percentage of 56\% (TG) to $29 \%$ (CG). Concerning the concept of technical drawing, TG students are better than "totally agreed students," in a percentage of $48 \%$ (TG) to $41 \%$ (CG). Concerning the concept of green architecture, TG students are better than "totally agreed students and agreed students," in a percentage of $87 \%$ (TG) to $59 \%$ (CG). On the overall evaluation, TG students are better than "totally agreed students and agreed students," in a percentage of $87 \%$ (TG) to $76 \%$ (CG), as shown in Table 1 and Table 2.

In the questionnaire, students were asked to rank the architectural and ecological concepts from 1 to 13 , depending on their priorities in the process of de- 
Table 3. Rating of house design concepts

\begin{tabular}{|c|c|c|c|c|c|}
\hline & & \multicolumn{2}{|c|}{ Test Group } & \multicolumn{2}{|c|}{ Control Group } \\
\hline & & Ranking & Percentage (\%) & Ranking & Percentage (\%) \\
\hline \multirow[t]{4}{*}{ Architectural criteria } & Functional use & 1 & 12,71 & 1 & 12,93 \\
\hline & Zoning & 2 & 11,61 & 3 & 10,28 \\
\hline & Architectural Aesthetics & 5 & 8,93 & 5 & 9,95 \\
\hline & Use of scenery & 6 & 8,41 & 2 & 12,22 \\
\hline \multirow[t]{9}{*}{ Ecological criteria } & Orientation & 4 & 9,08 & 4 & 10,08 \\
\hline & Energy efficiency & 8 & 6,98 & 9 & 5,75 \\
\hline & Comfort zones & 7 & 7,31 & 10 & 5,56 \\
\hline & Solar energy use & 3 & 9,08 & 6 & 8,99 \\
\hline & Wind energy use & 9 & 6,31 & 8 & 5,82 \\
\hline & Contribution to recycling & 11 & 5,16 & 12 & 3,81 \\
\hline & Reduce water consumption & 13 & 4,40 & 13 & 3,49 \\
\hline & Use of recycled and sustainable materials & 10 & 5,54 & 11 & 5,11 \\
\hline & Use of shades to prevent sun & 12 & 4,49 & 7 & 6,01 \\
\hline
\end{tabular}

Ranking: 1 (most desired), 13 (less desired)

Percentage: Rate of selected concept vote to whole group votes.

signing a house. Questionnaire results were compared between test and control groups, in order to demonstrate the architectural and ecological concept rankings (percentages) of the designed houses. As seen in Table 3, such concepts as zoning, energy efficiency, comfort zones, solar energy use, contribution to recycling, reduce water consumption and use of recycled and sustainable materials, appeared high in percentage compared to control group.

The results showed that basic design concepts and the awareness on these issues are improved as well as green architecture concepts in the test group. This means that when students are introduced to environmental issues on architecture, their awareness and performance improves.

\section{Case Study No 2: Advance Sustainability Issues in Third Year}

\section{Computer Aided Design and Building Performance Simulation Literature}

Advances in computer technology and their simple use, have made computer a common tool in building design and performance analysis..$^{32}$ Design education based on computer technology is important to raise the quality in education and presentation of the quality to international platforms. In rapidly evolving software and digital media, it is necessary to introduce architectural design theory, method, models and educate students in this respect. ${ }^{33}$

Building energy performance refers to the energy used or consumed for the existing or designed building. Building energy performance simulations are developed to maximize building's performance; to optimize consumed energy, and to make energy analysis and modelling. The basic theory behing these simulations depends on heating/ventilating and air conditioning loads, and calculating necessary overall energy.

Hui adressed the issues of simulation software use and its reflection on the educational process in environmental design. ${ }^{34}$ Frequent use of building performance simulation software in architectural design recently brings simulation education to the front. The method and content of this education and the researches in this literature is summarized below.

The computer aided studies that Tusckinski made in Stuttgart University undergraduate level courses ${ }^{35}$ focused on basic knowledge of the main stages of bioclimatic architecture and calculation of heat loads in buildings. In later studies of higher levels, the focus of education shifted to the theoretical seminars parallel to design studios, and analysis has been made using interactive simulation programs. In addition to that, in an another study, Hand and Hensen upgraded per- 
formance simulation education from phd studies to undergraduate level Strathclyde University in Scothland. ${ }^{36}$

Fuchs and Simon had suggested an integrated method of modelling and simulation teaching for undergradute studies in architecture in Switzerland Winterthur Technical School. They aimed to test design ideas in a quick and efficient way. ${ }^{37}$ In this method, modeling process of architecture students in education is based on both formation of design decisions supported by theorical information and evaluation of the results. Mahdavi has developed a method in the field study at University of Vienna to determine the time and effort for creating a software which will be used for the purpose of enhancing the building energy performance. ${ }^{38}$ In this method, 6 pre-determined school projects were shared between a group of 10 and modelled (time measurement has been made), and these were scored according to categories of energy, context and health. Thus, the results have been compared with results of another experienced $\mathrm{PhD}$ student as well as compared with each other on the basis of performance. Similarly to Hand's researches, it has been observed that the building modelling part was the most time and effort consuming according to results of surveys based on pre-test and post-test method.

Unfortunately, on the educaitonal agenda of many institutions, there are still outdated (40 years old) implementations. In the 1970s, Szokolay stated that starting education on the first environmental design studios caused a reaction of some 'traditional' minded faculty members and many debates occured supporting that design ideas would be mechanised and drifted apart from human values. ${ }^{39}$ Now it has become clear that architectural education without the knowledge and information of environmental design, restricts the architectural ability of new generation architects.

\section{Method of the Study}

This study has been conducted to experience simuation aided design process on ecological design approach to integrate Architectural Design Studio and Physical Environment Control I \& II courses. This study aiming to direct ecological design education in a scientific and reliable method, places simulation based ecological design education to be accomodated in the intersection of interdisciplinary fields, Figure 3.

In this study, Architectural Design Studio (M301),

\footnotetext{
${ }^{36}$ Hand, Hensen, 1995, p. $346 . \quad{ }^{38}$ Mahdavi, El-Bellahy, 2005, p. 1651.

${ }^{37}$ Fuchs, Simon, 1995, P. $362 . \quad{ }^{39}$ Szokolay, 1970.
}

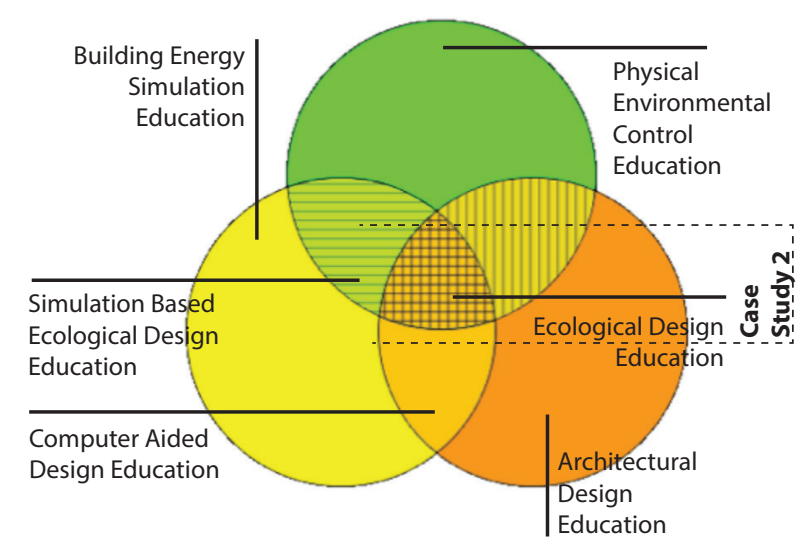

Figure 3. Integrated system model scheme.

Physical Environmental Control I \& II (M207-M212) courses which provides infrastructural support in 'physical environmental control, and Building Information (M363) elective course which provides simulation aided ecological design; have been programmed to support each other. Test group and control group were given the same site and architectural program in Design Sudio. They have already enrolled in Physical Environmental Control I \& II courses, so we assume that they have background knowledge on sustainability issues. Additionally test group students took Building Information course simultaneously with the Design Studio, where control group students have followed the regular routine. Design studio and elective course process are followed, questionnaries, midterm exams, and the final projects of the students are evaluated for a comparative study.

This study provides an experimental study for the use, measurement and development of integrated knowledge between disciplines.The main purposes of this study are:

- The integration will be achieved between theory and practice, by increasing the input to the Design Studio from the Physical Environmental Control courses.

- Building performance simulation introduced in Building Information course is expected to contribute architectural design process, designs should be developed with quantitative and qualitative values.

- In addition to the understanding and development of the 3D feature of building performance simulation, students will better comprehend the thermal performance analysis with the trial/error method. 
Table 4. Integration of Studio and Elective Courses depending on SOLO Classification ${ }^{[27]}$

\begin{tabular}{|c|c|}
\hline & $\begin{array}{l}\text { Understanding and } \\
\text { Comprehension Level }\end{array}$ \\
\hline$\underset{\mathbf{i}}{3}$ & $\begin{array}{l}\text { Pre-structural Level } \\
\text { Introduction of basic definition } \\
\text { and information }\end{array}$ \\
\hline $\begin{array}{l}3 \\
\dot{+} \\
m\end{array}$ & $\begin{array}{l}\text { Uni-structural Level } \\
\text { Setting up connections, } \\
\text { understanding of the problem }\end{array}$ \\
\hline 3 & $\begin{array}{l}\text { Multi-structural Level } \\
\text { Sorting, classification, } \\
\text { identification, listing and } \\
\text { merging }\end{array}$ \\
\hline$\frac{3}{\frac{3}{1}}$ & $\begin{array}{l}\text { Relational Level } \\
\text { Comparison, explanation of the } \\
\text { reasons, integrating, analyzing, } \\
\text { correlation and application }\end{array}$ \\
\hline$\frac{3}{1}$ & $\begin{array}{l}\text { Extended abstract } \\
\text { Generalization, reflection and } \\
\text { production }\end{array}$ \\
\hline
\end{tabular}

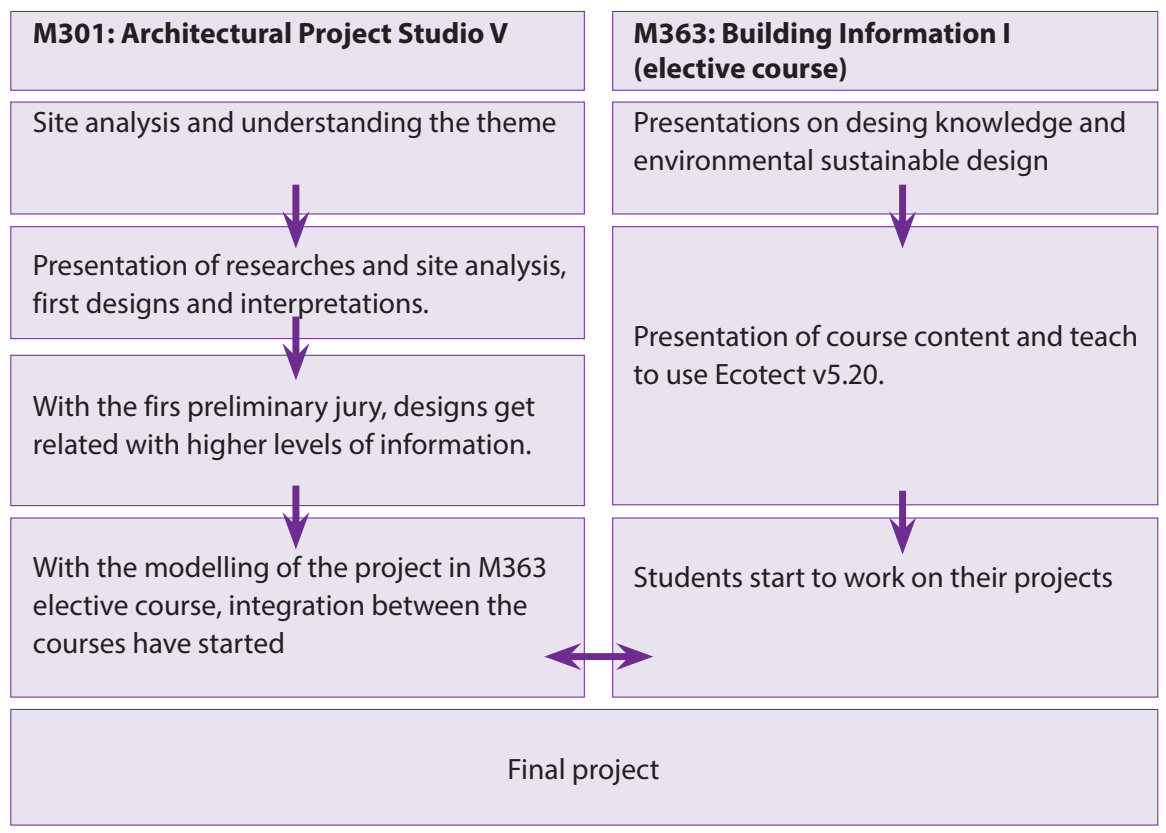

- The aim of this study is to raise awareness on energy-conscious ecological design development, with certain criteria evaluated in the early stages of conceptual design and their numerical data.

- Refutation of the belief that energy conscious ecological architecture and architectural design process are two different concepts, two processes should be integrated from the early stages of the design.

- Refutation of the belief that energy conscious ecological architecture has a certain type of form, put productivity/specificity/aesthetics aside.

- Building performance analysis is introduced to develop projects with early design decisions using quantitative feedback from the simulations.

\section{Design Studio Process (M301)}

Studio design education is organized according to the 15 week schedule. In the first 3 weeks site analysis and presentations are made, and a conceptual framework is established. The design studio has 8 instructors, who give panel critics, i.e. they criticize the projects as a jury, or give table critics (one to one) time to time (Table 5). The panel critics were given between the $4^{\text {th }}$ and the $8^{\text {th }}$ week and table critics were given between the $8^{\text {th }}$ and the $12^{\text {th }}$ week. The projects were finished between the $13^{\text {th }}$ and the $15^{\text {th }}$ week of the schedule and the final jury was made on the $17^{\text {th }}$ week. It has been observed that although panel critics are gener- ally preferred and are considered to be more useful to the students, one to one discussions and exchange of ideas are needed between students and advisors as table critics.

In addition to architectural design education, the primary goal of Design Studio, focusing on adopting and implementing energy-efficient ecological building design criteria, is to raise novice architects who are conscious of being responsible of designing spaces that represent maximum comfort and productivity by using minimum energy and expenditure as well as designing spaces that are friendly to the ecological system and natural environment. ${ }^{[26]}$ The themes which have been especially emphasized in energy-ecology efficient architectural context can be summarized into: recycling, reuse, waste re-acquisition, design and operation of passive systems (ventilation/air-conditioning/lighting), climatization based design, passive and active solar energy based technologies and conservation of energy. Further themes are:

- Raising awareness on inter-disciplinary and integrated design strategies focusing on natural resources.

- Working on applied teaching methods and energy efficiency based on energy conscious ecological environmental design criteria.

- Improving design practice by giving priorty to clean energy resources in terms of passive and active usage. 
Table 5. Integrated System Model between M301 - M363 courses

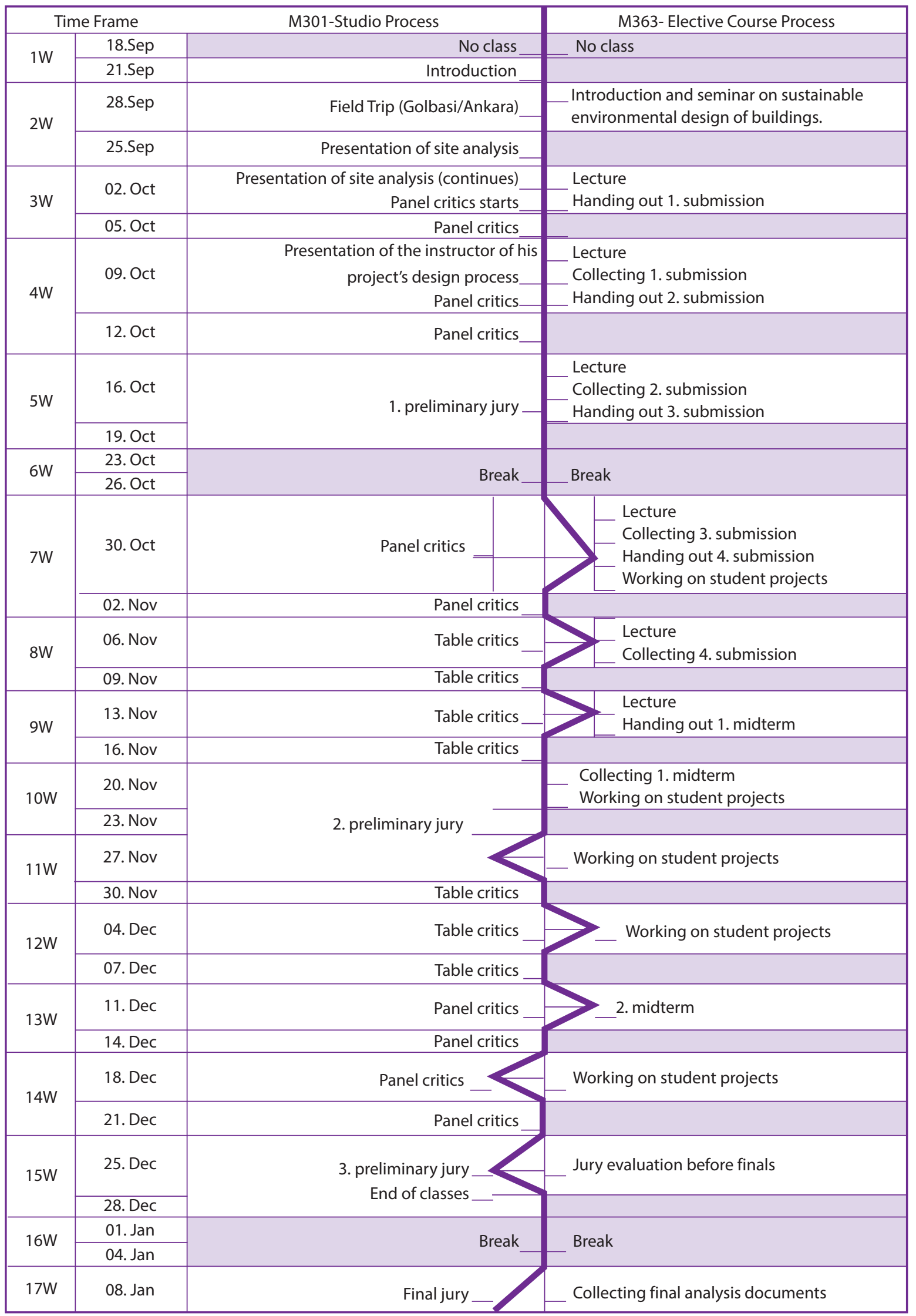


- Improving the design practice and approaches based on contemporary technologies, processes and products which effect the energy consumption directly or indirectly.

The specific descriptive principles of Design Studio's work, can be summarized as follows:

- Presenting relevant researches on energy and ecology in the context of both architectural programs in the early stages of the design development.

- Presenting personal experiences of faculty members in the field of energy and ecology.

- Developing designs with multi parameters according to energy and ecological criteria from the earliest stages of the design process.

- Developing the education in the studio, all the teachers and students participate in the critics in order to create a learning environment by hanging on the panel, discussing same problems and issues without the need to repeat to everyone.

- Encouraging students' participation in studio classes by recieving critics.

\section{Elective Course Process}

\section{(Building Information-M363)}

The basic building simulation concepts such as understanding the concept of 'simulation', learning the research methods, three dimensional digital modeling, understanding the concept of 'thermal zoning', analysis of climatization data, materials, shadows, shading and thermal calculations have been discussed on the first 7 weeks of the course and have been applied to pre-prepared examples. The students were expected to integrate these concepts to their studio projects between weeks 7 and 15 .

\section{Integration of the Processes}

The elective course and the design studio proceed simultaneously for the test group, support each other in a mutual feedback. The design studio sessions were made on Monday and Thursday afternoons ( 8 hours per week) and elective course was giving on Monday mornings ( 3 hours per week). The basics of building simulation were taught in the first 7 weeks of the elective course. After this period, the integration with the architectural studio was established. Hereby the issues about the simulations of the projects were discussed and critics were given in the elective course on Monday mornings and on the afternoons the inputs and effects of simulations were discussed during design studio (Table 5).
The data obtained from the behavioral pattern of students as a result of this integration model and experimental phases have been analized according to Biggs and Collis's SOLO classification (taxonomy of the Structure of the Observed Learning Outcomes). ${ }^{40} \mathrm{Ac}$ cording to this classification, student behaviors are based on 5 levels :

- The first week is introduction. The second week is pre-stuructural stage which focuses on the conceptual wireframe and basics. The correlations with the design problem itself is still not an issue at this stage. The basic principles are discussed via representations, analyses and data (Table 4).

- The representation of researches on the theme, site analysis and the early design ideas were discussed at studio on weeks 3 and 4 . This stage, described as uni-structural stage (Table 4), focuses on comprehending design problems and integration.

- The multi-structural stage which began with the pre-assesments of the jury on 5th week, focused on classification, identification and listing of information. The uni-structural and the multi-structural stages are the processes of teaching the software, theoretical subjects; stages can not be seperated from each other in the elective course. The integration of architectural design studio and elective course has still not been established until the $7^{\text {th }}$ week (Table 4).

- The integration process established through modeling the projects via simulation, getting data from the simulation, analyzing data, getting results and discussions of the results on studio between $7^{\text {th }}$ and $15^{\text {th }}$ week. This stage is discribed as relational and is based on analysis, comparison, and explanation of reasons, association and integration (Table 4).

- The $17^{\text {th }}$ week is the final jury week. The projects which are directed by the results of simulations were presented and discussed. This is the final stage which is discribed as extended abstract stage focused on generalization, reflection and generation (Table 4).

This taxonomy is explicitly used by Hamza and Horne ${ }^{41}$ in a similar way of integrating education. As mentioned before they conducted their study in Northumbria University, and aim to develop strategies to achieve energy conservation in design process. Their

\footnotetext{
${ }^{40}$ Hamza, Horne, 2007, p. $3841 . \quad{ }^{41}$ Hamza, Horne, 2007, p. 3841.
} 


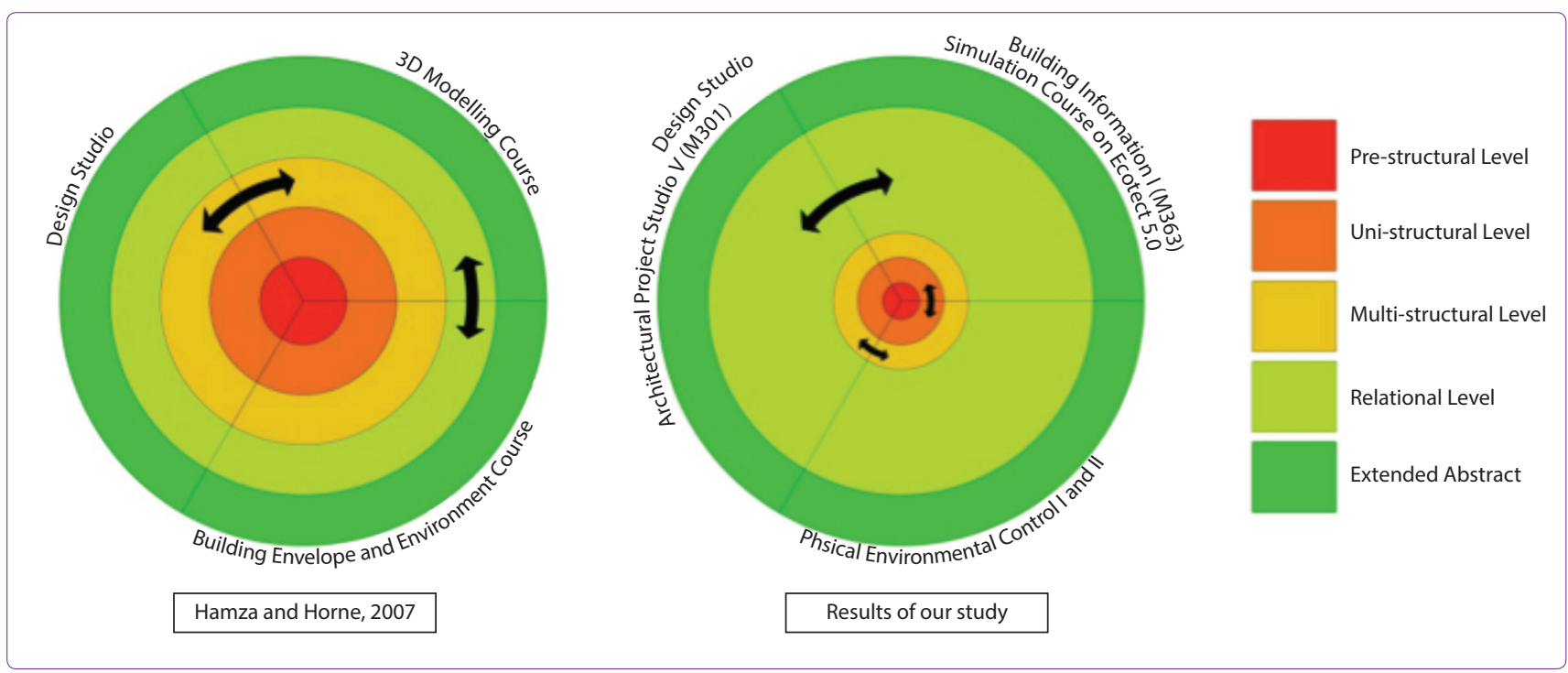

Figure 4. Improvence of integration between design studio, simulation course and theoretical courses; incomparison to the work of. ${ }^{[17]}$
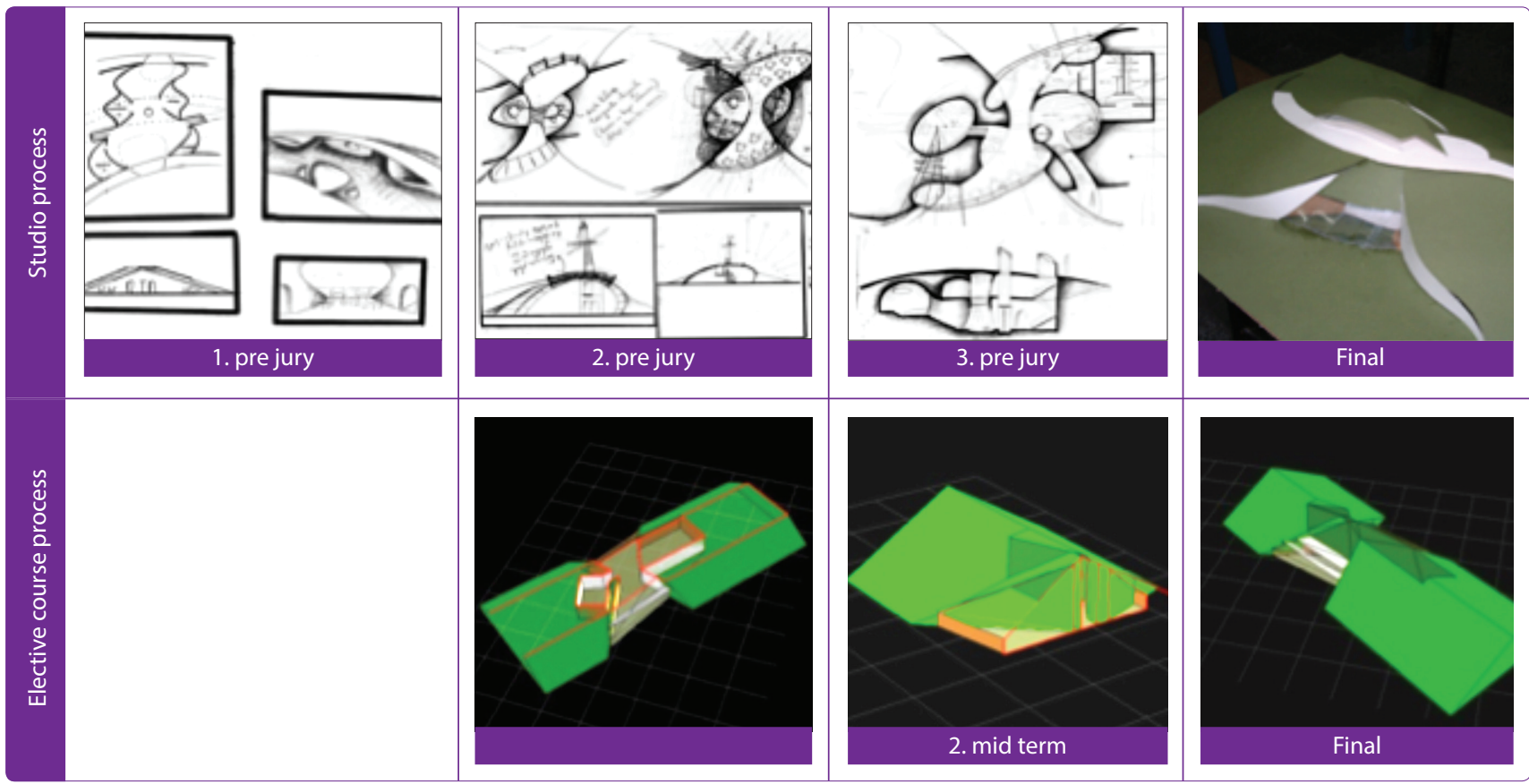

Figure 5. Development process and results of the project p1 (test group).
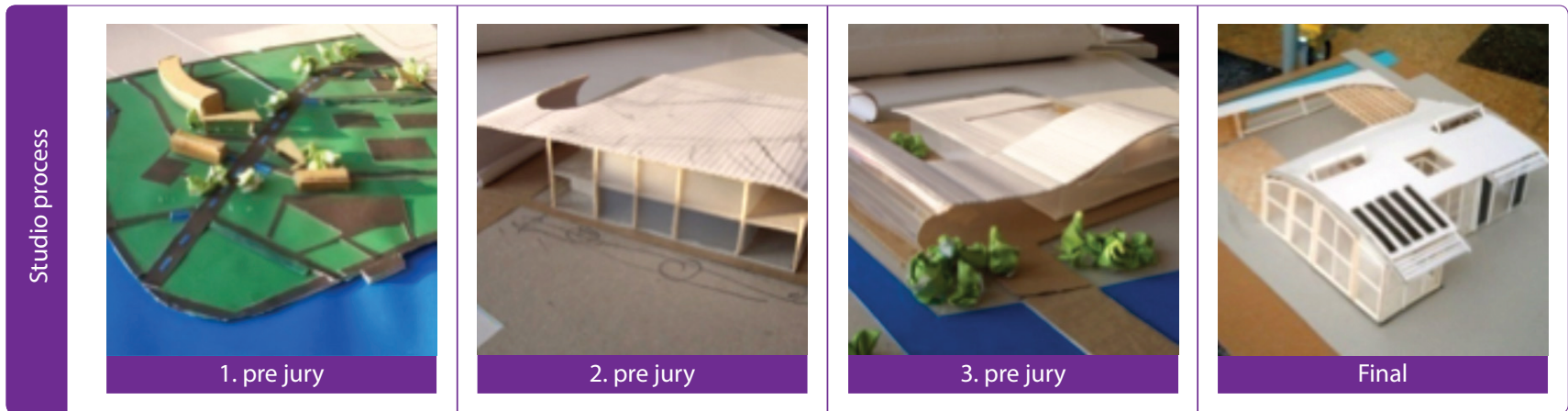

Figure 6. Development process and results of the project p4 (control group). 
Table 6. Comparison of test and control group students on architectural criteria of 'site' and 'building' depending on the ratio of integration

\begin{tabular}{|l|c|c|c|c|}
\hline $\begin{array}{l}\text { Site } \\
\text { - Site planning desicions } \\
\text { - Site-context relationships } \\
\text { - Site-building relationships }\end{array}$ \\
\cline { 2 - 6 }
\end{tabular}

project basically integrates 3 course modules; 1 . Design studio, 2. Building envelope and environment, 3. 3D modelling courses. When we compare our results to their work, results of our study came up better in terms of integration. Since Hamza and Horne's work achieved multi structural level in the middle of the semester, our work has pulled multi structurel level to earlier times in the semester ( $5^{\text {th }}$ week) (Figure 4$)$.

\section{Section Results}

It is observed that there are significant diversi-

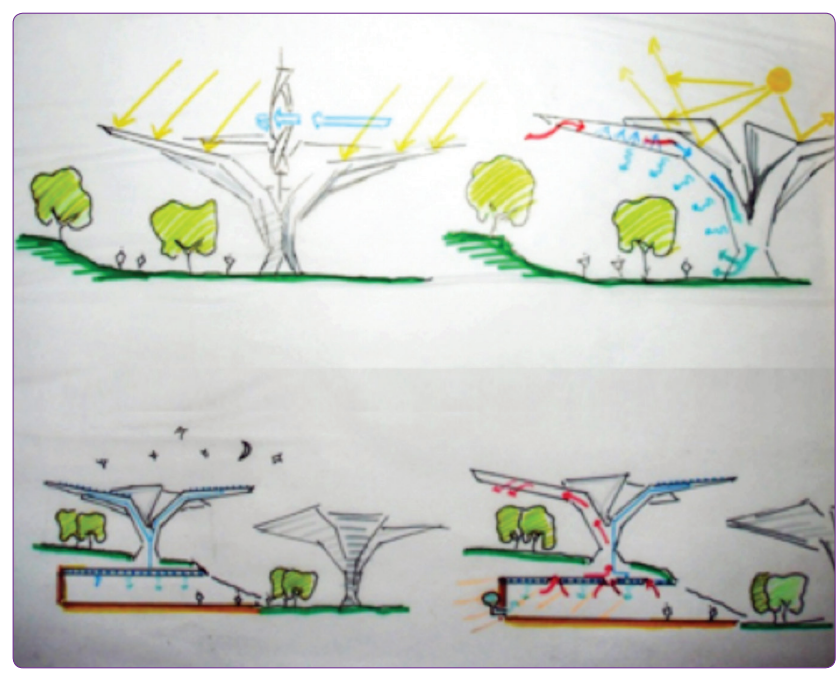

Figure 7. Preliminary skecthes about the ecological suggestions of a student. ties especially in landscape of design and reflection of building criteria to process, according to analysis based on architectural criteria. Focusing on topics such as decisions of the landscape/landscape-context relations/landscape-building relations which are under the criteria of 'landscape design' was more intensive in first weeks and diminished gradually in time until the end of the process of the test group. Discussions about space/function/program which are examined under the 'building' criteria seem to be the reason of this degradation. On the other hand, the students in the control group could not manage to fully develop their designs because of long term discussions about landscape/context which prevented them from studying in the building scale (Figure 6). Succession of students' work in Test Group is directly relevant with the simulation study. It is believed that the students were encouraged to work harder and became more productive with this method of research (Figure 5, 7).

Relevant to energy-ecology analysis, one of the most important result which is the outcome of simulation education is backdating two very important criteria such as 'solar control' and 'energy conservation' to the first weeks of the design process. The students of test group discussed and worked on the subjects such as control of transparent surfaces and shading, which was examined under the 'solar control' criterion from the begining of the design process. On the contrary, the students of con- 
Table 7. Comparison of test and control group students on energy-ecology criteria of 'sun control' and 'energy conservation' depending on the ratio of integration

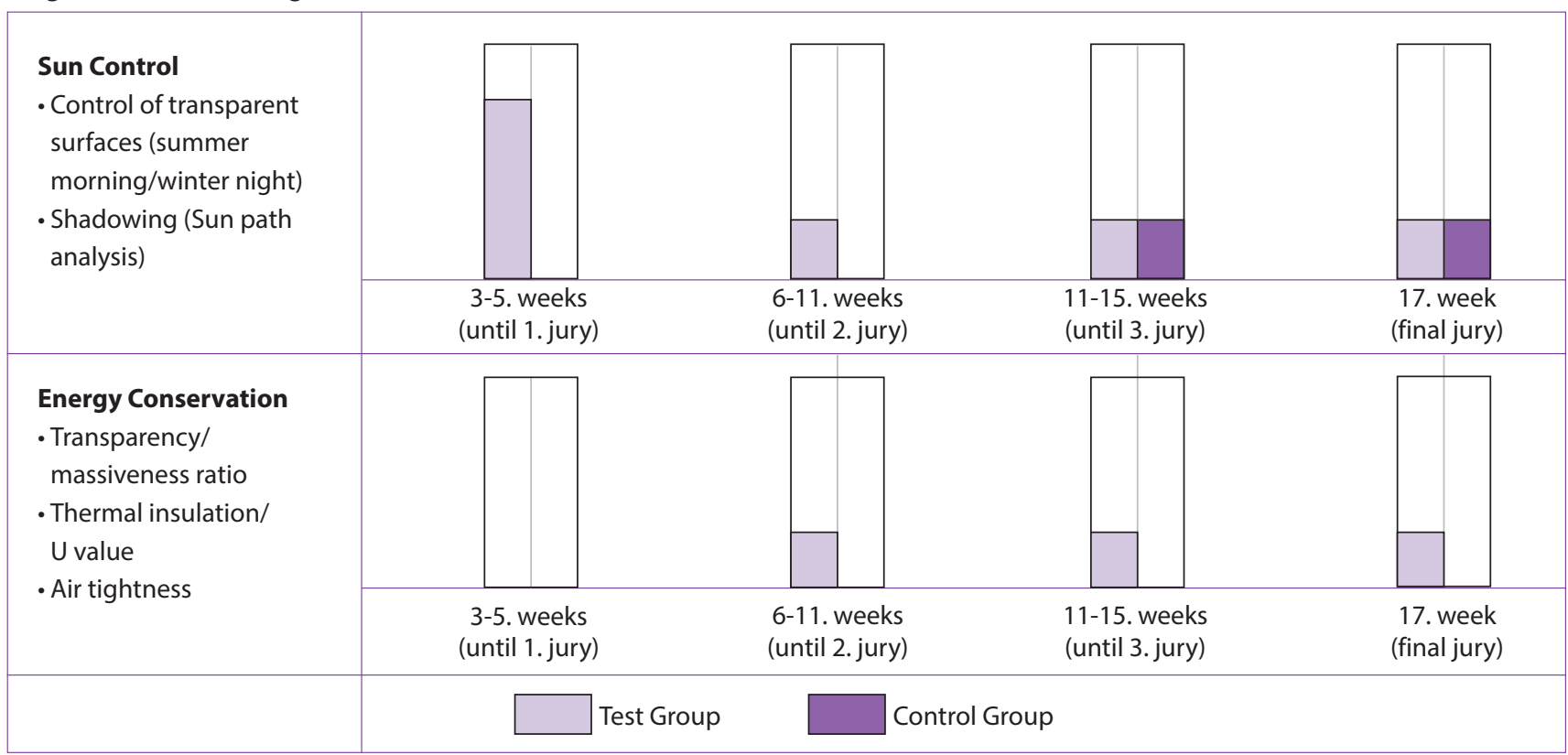

trol group took an interest in these subjects at the end of the process and they didnt give any attention about the subjects such as transparency/occupancy rate, heat insulation/u values, air tightness which are examined under the 'energy conservation' criterion. Ecotect v5.2 software which generates simulations based on the afore-mentioned criterion of energy conservation, en- couraged the students of the test group to study these subjects more intensively (Table 6-8).

As for the results, the advantages/disadvantages of the building performance simulation education can be summarized as follows:

- It was expected from the students to integrate the

Table 8. Comparison of two case studies depending on NAAB Criteria

\begin{tabular}{|c|c|c|c|}
\hline & & $\begin{array}{c}\text { NAAB Criterion on } \\
\text { Sustainability, } 2004^{[28]}\end{array}$ & $\begin{array}{l}\text { NAAB Criterion on } \\
\text { Sustainability, } 2009^{[1]}\end{array}$ \\
\hline & Awareness & Understanding & Ability \\
\hline $\begin{array}{l}\text { Case Study } 1 \\
1^{\text {st }} \text { year undergrad } \\
\text { architecture students }\end{array}$ & $\begin{array}{l}\text { Students gain awareness on } \\
\text { sustainability issues, built } \\
\text { environment and its } \\
\text { protection, basic energy } \\
\text { conscious ecological } \\
\text { approaches in design } \\
\text { education }\end{array}$ & - & - \\
\hline $\begin{array}{l}\text { Case Study } 2 \\
3^{\text {rd }} \text { year undergrad } \\
\text { architecture students }\end{array}$ & - & $\begin{array}{l}\text { Students gain understanding } \\
\text { on sustainability issues; have } \\
\text { the capacity to classify, } \\
\text { compare, summarize, explain } \\
\text { and/or interpret information }\end{array}$ & $\begin{array}{c}\text { Students gain ability in using } \\
\text { specific information on a } \\
\text { sustainable design task, } \\
\text { correctly selecting the } \\
\text { appropriate information, and } \\
\text { accurately applying it to } \\
\text { the solution of a specific } \\
\text { problem }{ }^{[1]}\end{array}$ \\
\hline
\end{tabular}


ecological design concepts with the first design skecthes. But in the overall results, the students who did not have an overall architectural design knowledge, cannot construct a sustainable design scheme. When another parameter is added to the problem, the students get confused. But in Case Study No 2, it is observed that the projects developed much better, when the students used performance simulations by evaluating/ experimenting/ performing ecological parameters.

- The study process was negatively influenced by the students' lack of 3 dimensional design skills. Design process is mostly going on plan and section drawings, hardly on relating to 3 dimensional space. Consequently, encouraging students to work on 3D model in Ecotect 5.0, reinvigorated their design.

- Students complained about their technical incompetence, such as wasting time to modelling and not having enough knowledge about the software. For better results, students must learn the software before-hand, and start the performance simulations later in the semester. In this respect, quality of the simulation software, compatibility with the other softwares, visual interface, and being easy to learn are also critical and important issues (Figure 8).

- Since students are not well equipped with energy-conscious ecological design knowledge, they were not creative enough to develop alternative solutions. This problem has reduced the quality of architectural and ecological values.

In order to implement a better study and get more efficient results in sImulation based ecological design education, 4 parameters; student factor, simulation software factor, studio environment/instructor factor and time factor should be considered.

The students must:

- Have adequate reading and writing skills in English

- Know 3D modelling and be capable of using it efficiently

- Have been enrolled and passed former theoretical courses, such as Physical Environmental Control courses with a satisfactory grade

- Be highly motivated to research and learn

- Be familiar to building simulation software, knowledgeable of modelling

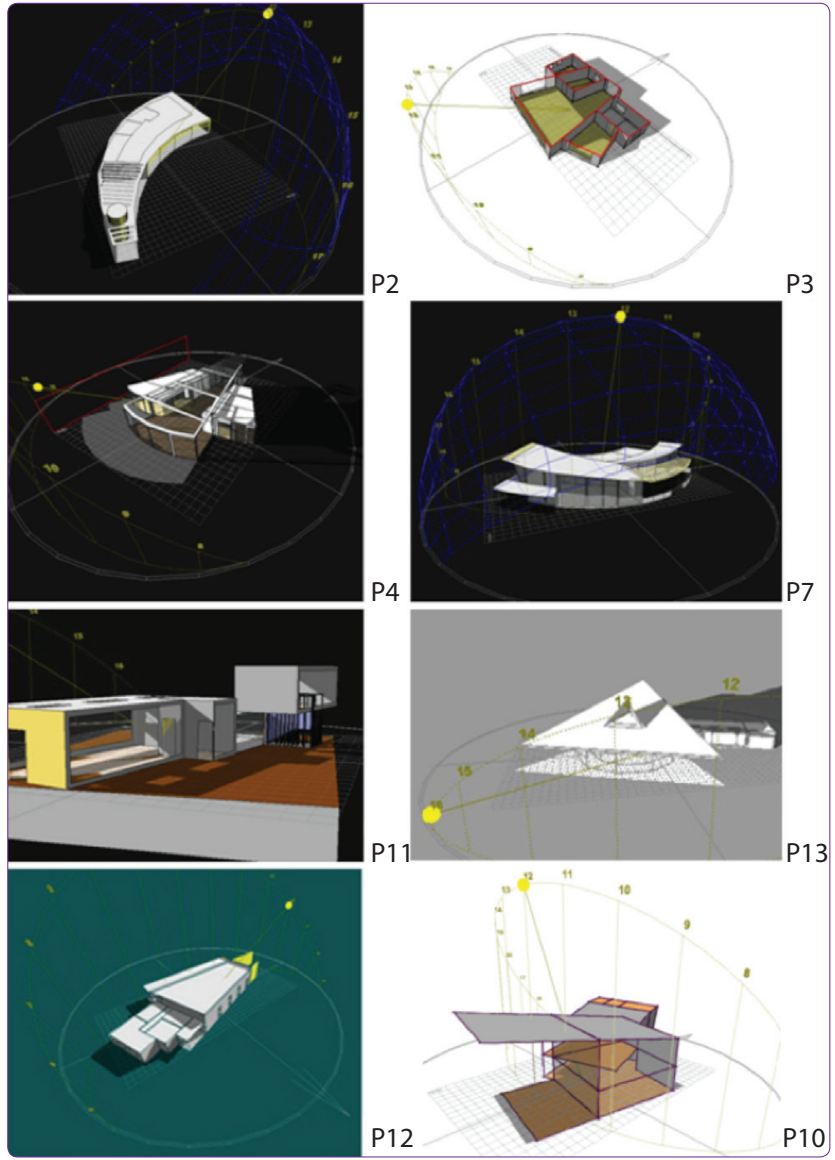

Figure 8. Final Ecotect images of various projects from the test group.

- Be skilled with 3D thinking and designing

Simulation program must:

- Have a very advanced user interface, and let the user model in a very short time.

- Be incompetable with other design software.

- Be able to design in every form, scale and material

- Minimize the errors in modelling, simulations and analysis

Studio environment must:

- Be used frequently allowing interaction between students and must give students disciplined study habits.

Instructors must:

- Be well equipped with energy conscious ecological design education.

Time must:

- Be efficiently used to learn simulation software and perform analysis. 


\section{Results and Conclusions}

These case studies demonstrate that desicions that are taken during the early phases of the design process play an important role in ensuring the performance of the end product. The main problem in such a knowledge based design process is the incapabilities of evaluating/interpreting the outcomes of intuitive decisions in order to provide reliable environmental sustainability criteria.

If we have a look at the history of NAAB Criteria, we can see the upgrade of sustainability issues in educational level. In the 2004 Edition, learning sustainability issue is oulined as follows:

"Understanding of the principles of sustainability in making architecture and urban design decisions that conserve natural and built resources, including culturally important buildings and sites, and in the creation of healthful buildings and communities." 42

In the 2009 Edition we can see the upgrade:

"Ability to design projects that optimize, conserve, or reuse natural and built resources, provide healthful environments for occupants/users, and reduce the environmental impacts of building construction and operations on future generations through means such as carbon-neutral design, bioclimatic design, and energy efficiency." ${ }^{43}$

Therefore; we have aimed to arrange our architectural education system; start with awareness of the subject, understanding of the problem in order to achieve ability level at the end. In this respect; Case Study No 1 aimes to raise awareness with the design exercises to introduce sustainability issues in the first year architecture students. Furthermore in order to meet MIAK and NAAB criteria, Case Study No 2 aimes to raise understanding and ability, with the integration of design studio and simulation aided building performance course (Table 8). The satisfaction of MIAK and NAAB criteria means that:

- Students gain understanding on sustainability issues and obtain the capacity to classify, compare, summarize, explain and/or interpret information.

- Students gain the ability to use specific information on a sustainable design task, correctly selecting the appropriate information, and accurately applying it to the solution of a specific problem. ${ }^{44}$

As the result of these studies it has been observed

\footnotetext{
42 NAAB 2004 Criteria. $\quad{ }^{43}$ NAAB 2009 Criteria. $\quad{ }_{44}^{4}$ lbid.
}

that in order to further develop ecological design aspects in architectural design education, the steps taken will substantially contribute to the education of novice architects. A powerful start will contribute to the development of future architectural practices, and let other disciplines adopt environmentally consciousecological design approach. In this respect, as being 'design studio instructors', we should be aware of our responsibility, and aim to educate novice architects who will built our future.

\section{Acknowledgement}

We would like to thank Prof. Dr. Gonul Utkutug, Inst. Dr. Idil Aycam, Inst. Dr. Gokturk Gultek, Tugrul O. Karaguzel, Bozkurt Gursoytrak, Yakup Hazan, Aytek Itez and Tansu Acimert for their contributions to the studio courses; and students for their invaluable work and enthusiasm. Part of this study was presented in EcoArchitecture Conference IV in Kos, 2012.

\section{References}

Al-Homoud, M. S. (2001) "Computer aided building energy analysis techniques", Building and Environment, 36, pp. 421-433.

Arkun, N.S., Kaya I.S., Onbilgin, T.T., Sayar, Y., Aritan, O., Atilgan, D., Ocal, C. (2000) Mimar Adaylarına Temel Tasarım Eğitiminde Uygulanan bir Program Üzerine Düşünceler, Mimarlık, 293, pp. 39-40.

Biggs, J., Collis, K. (1982) Evaluating the Quality of Learning: The SOLO Taxonomy, New York: Academic Press.

Fuchs, H. U., Simon, M. (1995) Teaching building simulation with the help of general purpose dynamical modelling software. Proc. of the IBPSA Building Simulation conference, Madison, Wisconsin, USA, pp. 362-369.

Hand, J. W. , Hensen, J. L. M. (1995) Recent experiences and developments in the training of simulationists, Proceedings of the IBPSA Building Simulation '95, Madison, Wisconsin, USA, pp. 346-353.

Hamza, N., Horne, M. (2007). Educating the designer: An operational model for visualizing low-energy architecture, Building and Environment, 42, pp. 3841-3871.

Hensen, J., Hraska, J., Mallory-Hill, S., Rabenseifer, R., (1998) Introducing IT-based environmental simulation courses at Slovak Technical Universities, Environmentally Friendly Cities, Proc. of PLEA, Lisbon, Portugal, pp. 623-626.

Hui, S.C.M. (1998) Simulation Based Design Tools for Energy Efficient Buildings in Hong Kong, Hong Kong papers in Design and Development, 1: pp. 40-46.

Koester, R. J. (2006) Centers for Regenerative Studies: Graduate Studio Experiences in Education for Sustainable Design. Proc. of PLEA2006, Geneva, Switzerland, 1, pp. 659-664.

Mahdavi, A., El-Bellahy, S. (2005) Effort and effectiveness considerations in computational design evaluation: a case study, Building and Environment, 40: pp. 16511664. 
Mayer, B. O. (2006) Ekolojik Tasarım Bilinci: Mimarlık eğitime yansıması üzerine bir deneme, Uluslar arası Ekolojik Yapı Tasarımları ve Malzemeleri Semineri, Chamber of Architects Antalya, Turkey, 11(1): pp. 45-60.

National Architectural Accrediting Board (NAAB) (2009) Conditions of Accreditation, July 10, Washington D.C. http:// www.naab.org/accreditation/2009_conditions.aspx.

National Architectural Accrediting Board (NAAB) 2004 Conditions of Accreditation, Washington D.C., http://www. naab.org/accreditation/2004_conditions_2.aspx.

Ozer, D. G., Satici, B., Turan, B. O., Soygenis, M. (2012) Raising awareness for sustainability in Basic Design, ed. By C.A. Brebbia, EcoArchitecture IV Harmonization between Architecture and Nature, WIT Press, UK, pp. 349-360.

Ozer, D. G., Utkutug, G. (2010) Bina Enerji Performans Simulasyonunun Mimari Tasarım Stüdyosuna Entegrasyonu, 1st International Graduate Research Symposium on the Built Environment, METU, Ankara, Turkey, vol. 2, pp. 4752.

Ozer, D. G., Utkutug, G. (2010) Enerji Etkin Ekolojik Mimari Eğitiminin Mimari Tasarım Stüdyosu Bağlamında İncelenmesi, Mimarlık Eğitiminin Dünü, Bugünü, Yarını Sempozyumu, Selcuk University, Konya, Turkey, 25-26-27 Nov., pp. 260-270.

Ozer, D. G., Harmankaya, Z. Y. (2010) Energy Conscious Ecological Architecture Education in Architecture Departments of Turkey, International Sustainable Buildings Symposium (ISBS), 26-28 May, Ankara, Turkey, pp. 862865.

Radovic, D. (1998) Ecophilosophy and education in architecture, Environmentally Friendly Cities, Proc. of PLEA'98, Lisbon, Portugal, pp. 627-628.

Roulet, C. A. (2006) Architectural Education for Sustainable Design, A Proposal for Improving Indoor Environment Quality, Proc. of PLEA, Geneva, Switzerland, 1, pp. 653654.
Schön, D. A. (1985) Educating the Reflective Practitioner, New York: Basic Books, Inc. Publishers, pp. 105-106.

Schön, D. A. (1987) The Design Studio: An Exploration of its Traditions and Potential, London: RIBA Pub. Ltd., pp. 70.

Szokolay, S. V. (1970) An Organization and Method of Teaching Environmental Design, Archea J., Eastman C.(eds), Proceedings of the Environmental Design Research Association, EDRA., 2.

Tabb, P., Rashed-Ali, H. (2006) Architecture Unplugged: The Teaching of the Principles, Needs and Calculation Procedures for Sustainable Housing Design, Proceedings of PLEA2006, Geneva, Switzerland, 1: pp. 623-628.

Tong, H., Cagdas, G. (Spring 04-05) Global bir Tasarım Studyosuna Dogru, Stüdyo, Tasarım Kuram Elestiri Dergisi, 3: http://www.studyomim.itu.edu.tr/sayi3/global_ bir_tasarim_studyosuna_dogru.pdf.

Tuschinski, M. G. (1995) Computer- Aided Training of Bioclimatic Architectural Design, experience with teachware for building performance prediction, Proceedings of the IBPSA Building Simulation 95, Madison, Wisconsin, USA, pp. 354-36.

Utkutug, G. (2007) GUMMF Architecure Department Studio 5, Studyo Illke ve Prensipleri, www.mmf.gazi.edu.tr/mimarlik/atolye5.

Yannas, S. (2006) Learning Environment, Proc. of PLEA, Geneva, Switzerland, 1, pp. 25-30.

Yeang, K. (1995) Designing with Nature, The Ecological Basis for Architectural Design, McGraw Hill, USA pp. 1-16, 187-211.

Key words: Understanding and ability; architectural design education; ecological awareness; MIAK and NAAB criteria; sustainability in design education.

Anahtar sözcükler: Anlama ve bilme; mimari tasarım eğitimi; ekolojik farkındalık; MIAK and NAAB kriterleri; tasarım eğitiminde sürdürülebilirlik. 